\title{
LA REVISTA ARIEL: MANIFIESTOS Y VOCES DE LA VANGUARDIA
}

\author{
Patricio Lizama A. \\ Pontificia Universidad Católica de Chile \\ plizama@uc.cl
}

Los estudios acerca del intenso debate artístico, político y cultural originado por las vanguardias en América Latina, han crecido en forma significativa a partir de las últimas décadas del siglo veinte. Los investigadores, junto al análisis de obras y autores del período, han realizado un trabajo destinado a comprender con mayor amplitud la fisonomía del campo cultural en sus respectivos países. La apertura ha sido muy productiva porque ha significado revalorizar las propuestas, tomas de posición y disputas de los nuevos sujetos e identidades culturales y ha permitido reelaborar una memoria, visibilizar procesos artísticos, reivindicar proyectos individuales y colectivos y trazar nuevas continuidades y genealogías.

Nuestro trabajo se inserta en este marco y se centra en la revista Ariel, órgano que se vincula con los partidarios del arte nuevo dentro y fuera del país, recibe el apoyo de intelectuales como Vicente Huidobro y abre espacio a las distintas modalidades de la poesía nueva. A la vez, la revista es una instancia que postula un orden cultural más abierto y una mayor autonomía para el arte, lo que la sitúa dentro del movimiento de renovación de los años veinte. Este, con nuevos sujetos e identidades culturales, con preocupaciones estéticas y políticas y con un discurso de raíces europeas y/o latinoamericanas, fue crucial en la apropiación y legitimidad de la vanguardia.

\section{VANGUARDIA ARTÍSTICA Y POLÍTICA}

El grupo “Ariel” está formado por cinco poetas, Fenelón y Homero Arce, Gerardo Moraga Bustamante, Juan Florit, Rosamel del Valle y un artista plástico, Efraín Estrada. Ellos tienen poco más de veinte años cuando, a principios de 1925, resuelven fundar una revista "y asustar con ella a los burgueses pacatos y detenerlos en su lectura de los poetas antiguos". Antes de publicarla, en marzo de 1925, escriben un manifiesto que lanzan desde los tranvías y pegan en las murallas del centro de Santiago. Luego de esta 
primera intervención pública, en junio del mismo año, aparecía la revista Ariel, publicación mensual de arte y crítica y meses más tarde, el segundo y último número.

El título declara la procedencia ideológica más visible del grupo. Rodó, a comienzos del siglo veinte, traza las líneas de su pensamiento en Ariel, ensayo que según su autor está inspirado en dos sentimientos principales: "mi amor vehemente por la vida de la inteligencia y dentro de ella, por la vida del arte, que me lleva a combatir ciertas tendencias utilitarias e igualitarias; y mi pasión de raza, mi pasión de latino, que me impulsa a sostener la necesidad de que mantengamos en nuestros pueblos lo fundamental de su carácter colectivo, contra toda aspiración absorbente e invasora" (xxvii). El texto tiene gran eco entre los jóvenes intelectuales del continente, porque Rodó los invita a trazar un programa propio, renovar los valores y comprometerse con una tarea de futuro que permita la unidad intelectual y moral del continente ${ }^{1}$.

Ariel es también un manifiesto que en contra de una cultura utilitaria que mutila y fragmenta al individuo, propone el desarrollo integral del hombre en el que destaca la eficacia moral de la educación estética y el protagonismo de la juventud en el pensamiento y la acción (Rodríguez 44). El ensayo de Rodó es, además, "la formulación de un modelo identitario de reivindicación, defensa e incluso exaltación de la manera propia de ser, la latina" (Devés 29), ideario que significaba para las naciones hispanoamericanas "formar y desenvolver su personalidad colectiva... el genio propio que imprima sello enérgico y distinto a su sociabilidad y a su cultura" (Rodríguez 51). Por último, el texto es un llamado a la construcción de un nuevo sujeto, un nosotros latinoamericano que supone una vuelta a "lo propio" y una resistencia al expansionismo norteamericano.

Los jóvenes creadores de la revista Ariel se sienten convocados a realizar esta labor cultural de inspiración latinoamericana y encuentran una posibilidad de canalizarla en la vanguardia artística, más que en la vanguardia política; por tanto, si bien no abandonan la búsqueda de una modernidad caracterizada por un nuevo orden políticosocial, su quehacer prioritario está en la creación de un arte que acoja y reelabore las propuestas de los movimientos vanguardistas y en la emancipación y autorregulación de las prácticas simbólicas. Este doble interés hacia lo artístico y lo político se expresa con claridad en la gráfica de la primera página de la revista.

El nombre de la publicación, Ariel, es un grabado en madera que está conformado a base de una matriz tallada en relieve con variadas incisiones, contrastes entre masas blancas y negras y un tramado que añade sombra. La tipografía de la palabra no posee terminaciones, los trazos de las letras son muy anchos y realizados a mano, cada tipo es diferente, porque al interior de cada uno existe un diseño singular y porque sus

${ }^{1}$ Rodó hace un llamado individual y colectivo que entusiasma a los artistas e intelectuales: "ningún otro espectáculo puede imaginarse más propio para cautivar a un tiempo el interés del pensador y el entusiasmo del artista, que el que presenta una generación humana que marcha al encuentro del futuro, vibrante con la impaciencia de la acción" (9). 
rasgos ascendentes y descendentes son todos desiguales, lo cual imprime a la portada de la revista un carácter propio e irrepetible, caracterizado por un cuidadoso trabajo de autor. El grabado en madera de Ariel indica el retorno a un modo de crear vinculado al quehacer manual del artesano, el regreso a la materia y la valoración de la naturaleza.

El grabado en madera, al mismo tiempo, es objeto de reproducción técnica y utilizado en la prensa popular: diarios, cuadernillos, hojas volantes y pliegos sueltos. Las experiencias de José Posadas en México y de los poetas populares en Chile que publicaban décimas en pliegos sueltos encabezados por grabados, publicación conocida con el nombre de Lira Popular, se inscriben dentro de estas expresiones presididas por una voluntad pedagógica, masiva y de bajos costos que denuncia las inequidades de la sociedad, ofrece una visión histórica alternativa y ocupa un margen construido por sujetos subalternos. Más tarde, el grabado es apropiado por el realismo socialista que lo convierte en instrumento educativo y de propaganda para la cultura de masas y le confirma una función ligada a la praxis política. La revista Ariel, al usarlo, cita la tradición de la prensa contestataria ubicada en los bordes, manifiesta su voluntad de ligarse a diseños políticos más amplios y evidencia en definitiva, su vínculo con la vanguardia política.

Advertimos así una tensión entre el mensaje de sustancia lingüística, Ariel, que sitúa a la revista dentro del modernismo hispanoamericano y el soporte que lo contiene, el grabado en madera, que la ubica en la vanguardia política. Ariel, el ensayo de Rodó, remite a un discurso culturalista y contemplativo más cercano al trabajo artístico; la palabra Ariel grabada en madera, a uno de combate y acción social, más próximo al trabajo político. La expresión Ariel, en esta revista, está entonces tensionada y resignificada, su ambigüedad es productiva, porque nos conduce al manifiesto de Rodó, a sus fundamentos grecolatinos, al cambio de siglo, al continente y, simultáneamente, se abre a la subversión de la vanguardia, a la ruptura con el mundo grecolatino, a las décadas del comienzo del siglo, a Europa. La revista Ariel acoge lo propio y lo ajeno.

El otro elemento gráfico de la portada es la palabra Manifiesto. Su producción es moderna, pues se advierte la huella de la máquina y de la producción en serie, de modo que, al igual que el grabado en madera, nos encontramos con un procedimiento objeto de reproductibilidad técnica que se dirige a un destinatario diverso y masivo. Los trazos verticales de las letras son finos, se estrechan en las uniones o al curvarse, son discontinuos porque no se cierran y los contornos abiertos se encuentran bien espaciados, de modo que configuran un juego de volúmenes que permite perfección y simetría, equilibrio formal y armonía interna. La revista, al usar la palabra Manifiesto, se inserta en la tradición inaugurada por el simbolismo, la de los movimientos que hacen públicas sus posturas iconoclastas a través de una estrategia de ruptura en el campo cultural. Además, el ícono direccional que destaca y atrae la atención sobre la palabra Manifiesto es cita del manifiesto dadaísta de 1918, otra manera de señalizar la filiación de Ariel con la vanguardia artística. 


\section{EL MANIFIESTO VISUAL}

El primer número de la revista se abre con una portada, donde encontramos dos Manifiestos que se articulan en dos soportes sígnicos: el discursivo y el visual. El visual es un dibujo de Efraín Estrada, que sitúa en primer plano la figura de un hombre mayor, bien vestido, de rostro serio y con una pipa en la boca que está sentado en un escritorio. Su mano derecha está algo atrofiada; la izquierda sostiene una pluma para escribir, cuya punta toca la superficie de una hoja en blanco; sobre el escritorio, al costado de la hoja, además, vemos una pipa y una pluma de pájaro. Detrás del sujeto, en el extremo derecho del dibujo, aparecen dos altos edificios que evocan las ciudades-torres de Le Corbusier y en el extremo izquierdo, un hombre pequeño lee sentado bajo un árbol en cuyas ramas se posa un pájaro, índice del componente autóctono de sustrato rural, de las tendencias que aspiran a crear un arte cuyos fundamentos se encuentran en el paisaje y de la concepción de América como naturaleza; al fondo, una locomotora detenida y delante de esta encontramos otra, en marcha, que surge de entre suaves colinas y deja una larga estela de vapor que asciende y semeja un conjunto compacto de nubes, figura que recuerda los trenes de Gino Severini. Sobre ambas, sobrevuela un aeroplano.

El intelectual de actitud hierática y de espaldas a la modernidad es un cuerpo tachado por numerosas líneas que lo fragmentan. Estas, horizontales, verticales y diagonales, que al mismo tiempo son el soporte de colinas y locomotoras, cruzan con exactitud sobre los brazos, el pecho y el rostro de modo que lo anulan en sus capacidades fundamentales: su visión y el alcance de su mirada; su voz y la autoridad de su palabra; su pensamiento y la capacidad reflexiva. El retrato está hecho con gran disciplina formal, pues el trazado respeta las leyes de armonía y proporción y las normas de la enseñanza académica. El sujeto maniatado se asocia a la locomotora detenida ubicada al fondo del dibujo la cual en su parte posterior se desvanece por el dinamismo y la velocidad de la otra locomotora. Este intelectual y la máquina inmóvil entregan la fisonomía de una sociedad tradicional y de un proyecto de desarrollo que, liderado por la constelación tradicional de elite, se encuentran dominados por la quietud y están ajenos a los cambios que supone la modernidad, proceso similar al experimentado por el arte académico respecto a la vanguardia. El mundo de este sujeto se fractura, entra en crisis y debe ser reformulado.

La sociedad emergente se visualiza de dos maneras complementarias. Los íconos de la modernidad y la civilización científico-técnica, la locomotora en movimiento, el aeroplano y los rascacielos, son cuerpos que no están tachados. El mundo del margen, compuesto por el lector y la naturaleza, articula otro cuerpo que tampoco está intervenido y que aparece próximo al de la modernidad; ambos mundos son configurados por líneas que convergen y se intersectan porque si "el reino mecánico deslumbra por su novedad y seduce por su promesa de cambio", el reino natural subraya la raíz y el vínculo profundo del sujeto con la tierra y la existencia de un arte que otorga categoría estética al campo. Los aparatos de la civilización industrial, si bien se constituyen como signos que irrumpen en medio de la ciudad, no logran enraizarse, aparecen como objetos "fuera de lugar" porque la urbe está deshabitada y el tejido urbano ha desaparecido debido al 
antagonismo vanguardista que ha borrado la cultura del pasado: la letra del intelectual y la ciudad de la tradición. Es necesaria, entonces, la mediación del otro intelectual, el que está en el margen, porque es él quien está convocado a desarrollar un nuevo proyecto que permita habitar un territorio y fundar otra ciudad donde se integren lo mecánico con lo natural, donde lo ajeno pueda converger con lo propio.

La escena por venir que implica desplazar al hombre en el escritorio para reemplazarlo por el otro bajo el árbol, se prefigura con las imágenes de la pipa y la pluma que ya ocupan un lugar en la mesa del intelectual de la sociedad en crisis. Estas imágenes, sinécdoque del artista y de su escritura, si bien no representan todavía al pensamiento operante, sí ya son visibles y se erigen como alternativas en el campo cultural, ya ocupan una posición que es precisamente la de la vanguardia: una posición por hacer. La escena que además supone fundar una urbe moderna que no pierda sus raíces, se prefigura también en la proximidad que el hombre bajo el árbol tiene con la máquina, cercanía que no se elabora de acuerdo a las normas académicas. Al contrario, las líneas forman un paisaje que tiene algo de imagen surrealista, ya que dos mundos extraños aparentemente inconciliables, lo moderno y lo rural, se encuentran en un espacio, pero por este mismo hecho, cada uno escapa a su identidad original para, en la relación entre ellos, transmutarse en otro, nuevo, resultante del roce entre lo ajeno y lo propio, entre modernización e identitarismo.

El dibujo de Estrada propone así tres escenarios que se imbrican y se interrelacionan. El primero es el del orden burgués que domina, pero que será desplazado; el segundo es el del margen que revela el encuentro del mundo propio - el mundonovismo y el arte nacional- con el mundo ajeno -el futurismo y el arte nuevo. El tercero es el que está por venir, la nueva ciudad que supone al intelectual que alcanza el centro y hace un arte híbrido, expresión original que no reniega del vínculo latinoamericano, como tampoco del aporte foráneo, la metrópoli cosmopolita, espacio de la modernidad que aproxima y entrecruza lo autóctono y lo exógeno, la cultura tradicional y la moderna. De esta forma, con un paisaje en movimiento que carece de horizonte fijo, queda delineada la gran utopía político-cultural que debe construir la juventud latinoamericana.

\section{EL MANIFIESTO ESCRITO}

El Manifiesto escrito se encuentra firmado por todos los integrantes de Ariel, excepto Fenelón Arce, y se erige como una intervención en el campo artístico que pone en escena a un sujeto colectivo. En el texto asoma una pluralidad de voces que se entremezclan y exhiben, una vez más, las tensiones entre lo ajeno y lo propio en términos artísticos y también histórico-culturales: el discurso del arielismo que remite a la juventud latinoamericana, el político-social que enfrenta a la sociedad oligárquica y repudia al burgués y el vanguardista de origen europeo que postula una creación acorde con la época y que también rechaza al burgués y al orden social. Los poetas enjuician un estado de cosas e identifican a sus oponentes, al advertir un gran antagonismo entre un ellos, "los hombres mercantilistas", y un nosotros, "la juventud pensadora". La oposición de raíz arielista devela la existencia de una sociedad cuyos rasgos más significativos se encuentran en una elite que olvidada de los valores humanistas, gesta un 
mundo excluyente dominado por el utilitarismo y el materialismo. Este poder aristocrático rige los ámbitos de la cultura, y con una actitud conservadora de "cómoda erudición", mantiene el arte sujeto a tradiciones europeizantes trasplantadas e ignora con desdén las manifestaciones originales del país, razones que impulsan a los integrantes de la revista a atacar la conformidad de la elite y a intervenir un gusto.

Los jóvenes rechazan esta sociedad y su "patraña señoril y paquidérmica", y se asumen como "espíritus libres" que viven un intenso periodo de transición, el cual comienza a detenerse, por tanto es el momento en que "los horizontes son más claros". Están situados en el umbral de un tiempo que comienza y por ello señalan que la nueva época abre a la juventud, verdadero sujeto del cambio, un gran porvenir lleno de posibilidades y conquistas. Ellos confirman su carácter vanguardista, pues participan de un movimiento rebelde que se ha anticipado a "esa retardada evolución histórica y política" y ocupan allí los puestos de avanzada. Sin maestros, enfrentados a un orden que favorece un arte caduco y a intelectuales que no irradian sabiduría, declaran ser capaces de interpretar y hablar en nombre de una generación y vivir una hora de polémicas y debates, de creación y júbilo. Los integrantes de Ariel se pliegan así al "nosotros" y una vez expresada su pertenencia a los grupos contestatarios, y construido este lugar de oposición, establecen los signos que distinguen a la revista.

$\mathrm{Su}$ nacimiento acontece en una sociedad que no ofrece espacios significativos al arte y donde las publicaciones existentes no responden a los intereses de los artistas de avanzada, de modo que Ariel surge en el margen. Este lugar posee una historia relevante, porque ya a comienzos de los años veinte se han generado aparatos alternativos de comunicación, en los cuales los miembros de Ariel se reconocen. Las revistas como Siembra, Juventud, Rodó y Claridad han impugnado las creencias, saberes y prácticas del pensamiento operante y han realizado una "protesta fervorosa" con el afán de romper "el espejo apolillado de las tradiciones" y dinamizar el campo de poder. El margen, además, posee una coyuntura favorable, porque allí convergen figuras cosmopolitas como Vicente Huidobro, el viajero vanguardista que difunde el arte nuevo y le otorga otro fundamento estético-ideológico a la publicación chilena.

La revista tiene como propósito, por una parte, plegarse a la lucha ideológica, transformar las estructuras y organizaciones de la institucionalidad cultural, con el objeto de dar cabida a pensamientos y visiones de los grupos subalternos y lograr grados más amplios de autonomía en el campo. Por otra, promover un arte que revele la contemporaneidad y un artista que pueda colocarse, no de espaldas como el intelectual burgués, sino "frente a frente a la vida actual para hacer arte actual, en un impulso de andar con la hora que anda". Por último, busca favorecer un arte que tenga una política orientada a rescatar las manifestaciones culturales relegadas y excluidas por el gusto operante, arte que incorpora a la naturaleza, porque si bien ésta ha perdido prestigio como fuente del arte, es rescatada por los miembros de Ariel en cuanto signo de lo propio. En suma, los poetas anhelan realizar una obra de "exaltación y dinamismo", aparece el lenguaje de filiación futurista, que acoge y legitima expresiones artísticas más plurales y que se enraiza en una historia particular.

El logro de estos propósitos pasa por abrirse al continente, el deseo de Rodó, y así el Manifiesto concluye con una apelación dirigida "a la juventud de Chile y de América" 
para que se haga parte de la publicación: "Ariel surge hoy enarbolando este llamado a la juventud ... De pie, agitando al aire de la tierra nuestro grito, vuelto el rostro hacia el Este y el Norte de América, en la convicción de que seremos oídos, echamos a rodar nuestra juventud en la honda iluminada de Ariel'. La convocatoria señala la utopía de los jóvenes arielistas y vanguardistas que se sienten preparados para emprender "la marcha hacia los cantos nuevos". Asimismo, explicita la voluntad de gestar redes entre los grupos latinoamericanos de avanzada, de ir más allá de las fronteras nacionales lo cual es un indicio de la desterritorialización de las culturas. Ellos se movilizan para salir del margen y ocupar un lugar central en la escena de la cultura chilena, lugar donde ya han puesto la pluma y la pipa.

\section{MODIFICAR Y CONSTRUIR}

Los poetas de Ariel anhelan impugnar el control oficial en la organización y las instituciones del aparato cultural, con el fin de ampliar los límites del campo, modificar las prácticas artísticas y sus condiciones de producción y recepción y, así, lograr mayores grados de autonomía. Se trata de intervenir el tramado del arte, desarticular "el círculo de telarañas" de la ideología dominante y, a la vez, construir y entronizar otro poder cultural alternativo.

La tarea implica el cuestionamiento de la hegemonía de los intelectuales de la elite que difunden la alta cultura europea, generan un ambiente intelectual marcadamente aristocrático, desarraigado, niegan las expresiones autóctonas y desfiguran la recepción de las tendencias vanguardistas. Ellos, aficionados que conocen los modos de hacer del arte, pero que no tienen un verdadero oficio ni asumen su actividad creativa como una profesión, ocupan importantes aparatos de formación y de comunicación, se empeñan en "no querer entender y menos aceptar el arte nuevo" y legitiman un arte del pasado. Por eso, afirman los miembros de Ariel, los diarios no dan cuenta de "la vida intelectual del país", las revistas son "caducas y apolilladas" y los ateneos reciben a "lo menos representativo de la juventud": es necesario desalojar estos espacios para instalar a creadores interesados en las problemáticas del siglo.

El trabajo para renovar los organismos oficiales se complementa con la construcción de un circuito cultural alternativo que legitima los imaginarios y sujetos emergentes, las voces contestatarias y el pensamiento crítico de artistas e intelectuales de avanzada. Esto significa difundir publicaciones e instancias de consagración autónomas de Santiago y de provincias, de modo que diversas revistas tienen cabida en Ariel. Clari$d a d$, publicación de los estudiantes universitarios, más cercana a la vanguardia política, posee gran circulación en el país y forma parte de la red de revistas de tendencia anarquista ${ }^{2}$; Pablo de Rokha, director de Dínamo, expresa su profundo desacuerdo con los representantes y la situación de la cultura, y convierte este órgano de provincia

${ }^{2}$ Ver el texto de Florencia Ferreira, Claridad y el internacionalismo americano. Buenos Aires: Claridad, 1998. 
en una "publicación depuradora de absoluta franqueza". Por último, Rodó, revista de carácter más modernizante y caracterizada por su difusión intelectual americanista, también es acogida en Ariel.

El establecimiento de redes, como se planteaba en el manifiesto escrito, traspasa las fronteras nacionales. Las relaciones de la revista chilena con otros artistas de Argentina, Uruguay y Perú, vínculos que se expresan en los libros y las revistas que se conocen y se citan, en las referencias y las manifestaciones de apoyo mutuas, en las preocupaciones artístico-culturales semejantes, indica la configuración de redes intelectuales muy actualizadas y de gran fluidez. En Ariel, publican sus textos Julián Petrowick, Juan Filartigas, Jacobo Fijman y Alberto Hidalgo, escritor este último que es muy relevante para la difusión continental de la obra de los poetas chilenos ${ }^{3}$. Además, encontramos reseñas de revistas uruguayas como Nueva Generación y de órganos vanguardistas argentinos como Martín Fierro, el periódico donde participan "los mejores valores actuales de la Argentina", Inicial, de vasta circulación en América Latina y Proa, "sólida afirmación del valor intelectual ... de la Argentina".

Las redes internacionales son recíprocas, pues los jóvenes chilenos publican y sus revistas son comentadas en numerosos medios extranjeros. En Martín Fierro se reseñan los textos de Rosamel del Valle y Humberto Díaz Casanueva; en Inicial aparecen poemas de Juan Moraga, Gerardo Seguel, Alberto Rojas Jiménez, Ángel Cruchaga, entre otros; la revista uruguaya, Nueva Generación, publica la poesía de autores como Juan Florit y María Rosa González. Julian Petrowick comenta el panorama intelectual chileno en Amauta; poemas de Rosamel del Valle y Humberto Díaz Casanueva aparecen en la limeña Rascacielos ex Hangar en 1926, y en Hangar ex Trampolín publican textos de Vicente Huidobro y Juan Moraga.

La gestación del circuito alternativo implica, asimismo, visibilizar otras instancias de circulación del pensamiento artístico-cultural y político-social. En Ariel se dan a conocer librerías que ofrecen sistemas de venta y suscripciones a revistas, periódicos y novedades literarias de Europa y Estados Unidos. Además, se informa la intención de fundar una editorial, otra instancia muy relevante y anhelo de muchos grupos de la vanguardia, pues los poetas chilenos anticipan las "Publicaciones Ariel" que aparecerán anexas a la revista y que se iniciarán con El espejo atrabiliario de Rosamel del Valle, estrategia que no alcanzó a fructificar. Por último, anuncian libros de temas políticosociales y textos literarios por aparecer, de autores como Borges, Oliverio Girondo, Raúl González Tuñón, Evar Méndez Rubén Azócar, Pablo Neruda y Rosa González.

${ }^{3}$ Las relaciones con Hidalgo tienen gran importancia para los miembros de Ariel, porque con Borges y Huidobro coeditan el Índice de la nueva poesía americana en 1926, volumen que reúne a sesenta y dos poetas vanguardistas de diez países. De esta forma, a través de las redes intelectuales de la época, la poesía emergente de Chile se pone en la escena latinoamericana, porque figuran en el Indice... dieciséis escritores, entre otros, Ángel Cruchaga, Juan Florit, Rosamel del Valle, Pablo Neruda, Pablo de Rokha, Gerardo Seguel, Juan Marín y, por cierto, Huidobro. 
El esfuerzo por desarticular y construir no es algo solo de la literatura, sino que se extiende a otras expresiones del arte, expansión que permite a la revista convertirse en un espacio de los partidarios del arte nuevo y favorecer la consolidación de un frente amplio de vanguardia que se moviliza para alterar el campo cultural. La situación de la plástica es tratada en Ariel de acuerdo con las líneas centrales de la revista y en esos términos, constituye una cifra del enfoque cultural que la sustenta. Primero, se destaca la crisis del control simbólico en la Academia de Bellas Artes, institución crucial para las fuerzas conservadoras en el campo plástico. Luego, se subrayan las estrategias de resistencia implementadas por los alumnos de la Academia. Ellos forman un "grupo libre" que pretende "derribar los viejos preceptos académicos", porque no desean seguir "aferrados al servilismo oficial" y, al mismo tiempo, proponen ámbitos autónomos de circulación artística, pues pretenden montar una "Gran Exposición de la Juventud" que se dedicaría a José de Vasconcelos y al gobierno revolucionario mexicano. Finalmente, la revista Ariel difunde dos discursos complementarios de la vanguardia plástica, porque si en el primer número aparecía el dibujo-manifiesto de Estrada -más cercano a la modernidad y a los planteos europeos-, el mismo autor en la portada del segundo número se inclina por el arte latinoamericano al presentar un retrato indígena.

La impugnación al entramado cultural y la ampliación de los límites del campo pasa, en último término, por modificar el imaginario asignado a la mujer dentro del sistema patriarcal. Aunque esta problemática no aparece abordada con una perspectiva radical, sí logra posicionarse, al señalar la existencia de un sujeto que aspira a una legítima representatividad y a una distinta colocación en el campo cultural. El uruguayo Juan Filartigas escribe acerca de Teresa Wilms y sostiene que la vida de la escritora chilena transgredió el imaginario femenino, fue más allá del territorio adjudicado por el sistema patriarcal: "no ambicionó ser reina, sino artista".

El énfasis de Filartigas, más que denunciar y desmontar el sistema de dominación, está puesto en caracterizar a Wilms como una mujer que, atraída por el misterio, renegó de su origen y de su mundo y vivió para procurarse una posición en el campo artístico y cumplir el anhelo de su vida. Escritora con varios libros de carácter modernista publicados en Perú, Buenos Aires y España, terminó su existencia de modo trágico en París y su gesto final es una protesta contra la sociedad conservadora que la condenó y terminó por derrumbarla. Wilms aspiraba a "la celeste locura de lo imposible", pero el acoso de la ley, la moral y las costumbres confirmaron que la osadía de su libertad y su migrancia tenía un límite y no había lugar para la mujer que se divorciaba, se alejaba del país y elegía el arte como escenario para darse una identidad.

\section{DESINFECTAR Y DISEMINAR}

Los artistas de Ariel se incorporan a la disputa por la definición del metatexto artístico. Desean "derribar los viejos preceptos académicos" y con ese objeto se insertan en el debate para cambiar el gusto, alterar el canon vigente y postular otro que renueve el horizonte de expectativa existente en el arte: hay que "desinfectar los oídos y los ojos".

La tarea inicial es identificar a los autores anclados en el pasado y a quienes los consagran, labor que ellos realizan con otro rasgo propio de la vanguardia: el humor. 
En las páginas de Ariel, es sistemática la oposición a un arte viejo que se encuentra "fuera del siglo, apolillado y que hiede a muerto" y a sus cultores que hacen una obra inspirados en una poética de filiación romántica. Estos aficionados poseen una concepción convencional de la poesía centrada en el yo, de modo que sus textos ofrecen un" panorama a su imagen y semejanza". Asimismo, los poetas de Ariel cuestionan a los modernistas como Leopoldo Lugones o Francisco Villaespesa, “autor de 130 volúmenes de hojarasca y humo" que escribe "poesía leprosa en este siglo de aviones, jazzband". También rechazan a los artistas chilenos, como el escritor Mariano Latorre y el pintor Alberto Valenzuela Llanos, ambos ligados a una representación imitativa de la realidad. Los críticos, "veteranos arqueológicos", no escapan a la mofa porque alaban un arte caduco y sus juicios se fundan en una "estética a receta fija".

La diseminación del arte de vanguardia, la apertura a nuevas formas de subjetividad y a actores emergentes que plasman las imágenes de la época que nace, conforma otra labor crucial para modificar el gusto y producir la creencia en la obra vanguardista. Los poetas de avanzada están con el siglo, les atraen los nuevos imaginarios, el "vasto trepidar de motores, de almas" y con rebeldía, hacen una relectura de la tradición y experimentan con nuevas formas de representar. Para ellos, señalan los jóvenes de Ariel, el arte es descubrimiento en cuanto el artista es concebido como un sujeto atraído por la novedad de la vida moderna y por las creaciones de la civilización científico-técnica, las indagaciones acerca del yo y los problemas metafísicos. El arte también es conquista, pues el creador, enfrentado a estas nuevas zonas de realidad, reniega de lo que le han enseñado y elabora un lenguaje singular que busca aprehender los cambios convirtiéndose en un "cazador de palabras" que, con voz propia, traza un nuevo panorama, porque no hace arte a "imagen y semejanza del yo", como los románticos sino a "imagen y semejanza del mundo".

Los miembros de Ariel se proponen dar a conocer las tendencias vanguardistas, "arte novísimo. Creacionismo, Dadaísmo, Futurismo, Ultraísmo, etc.”, y comienzan con Vicente Huidobro, autor que había regresado al país en 1925 y a quien le dedican un homenaje a página completa. Este contiene la opinión de algunos directores de Ariel sobre el escritor y dos poemas huidobrianos, uno en español y otro en francés. Ellos destacan su capacidad para vivir en medio de una civilización en crisis, comprender la radicalidad del cambio epocal y representarlo artísticamente con un lenguaje que constituye una nueva metáfora epistemológica: él está "con el siglo". A la vez, valoran al artista que explora y revela zonas de realidad desconocidas, quehacer que lo sitúa como un adelantado que rompe con los marcos vigentes de la poesía hispanoamericana: él es "bandera de avanzada" y torre que "horada los cielos... en busca de constelaciones desconocidas".

Los poemas huidobrianos publicados son "Ete en sourdine" y "Torre Eiffel", este traducido por Rafael Cansinos Assens. En estos textos creacionistas notamos la expansión del soporte lingüístico de la escritura poética, el que se amplía con la influencia de la plástica: ausencia de puntuación, estrofa y verso que se descomponen y fragmentan, desarticulación de un orden que se reemplaza por otro que posee una cohesión distinta y produce un atrayente efecto visual. El poeta dispone el texto en la página y juega con los espacios y blancos, la variedad de sangrías, la diversidad tipográfica y la 
ubicación de las palabras en distintas posiciones, como en este último poema, donde la escala visual para subir a la torre es, al mismo tiempo, una escala musical. La Torre Eiffel, otro ícono de la modernidad, le permite a Huidobro evidenciar cómo se transforma la realidad objetiva y se crea un poema: un "hecho nuevo".

El homenaje de Ariel es al escritor que se aleja de las preferencias y los modelos legitimados, que abre espacios decisivos para la poesía chilena e hispanoamericana, y que instala una fractura dentro del sistema expresivo de la época con su poesía y su reflexión artística. Su propuesta, elaborada de preferencia en Europa, es comentada no por primera vez, pero sí con mayor atención y amplitud en Chile en $1925^{4}$ y logra un impacto que tiene variados efectos: vitaliza y tiene resonancia en la escritura de jóvenes, los que, sin ser discípulos, adhieren y comparten una poética; da cuenta de una creciente heterogeneidad en la literatura nacional, e indica cómo ésta comienza a organizar y a transformar el ingreso de los textos que vienen de afuera y a definir su recepción. No se puede olvidar la otra dimensión del escritor, la del que moviliza y alienta a los artistas a comprometerse con el oficio: él acompaña a los integrantes de Ariel en la publicación de la revista ${ }^{5}$ y los vincula con escritores y grupos extranjeros.

El homenaje es al escritor que desarrolla una actividad política al regresar a Chile. Ya a fines de 1924, en París, Huidobro declara que desea volver a Chile "para hacer la revolución". Y agrega: "Mi anhelo más alto es crear un país", de modo que al llegar a Santiago se transforma en el intelectual que entiende el malestar y las aspiraciones políticas y culturales de los sectores contestatarios y hace públicas sus opiniones para denunciar la descomposición del orden político. Su discurso se une a las voces críticas del movimiento renovador existente en Chile, pues señala la prolongada crisis de un modelo de sociedad que se agota, de un antiguo régimen que ha perdido legitimidad y que tiene arruinado al país. La clase política y el aparato público están corrompidos y sus vínculos con el poder económico derivan en grandes pérdidas para el Estado. A su vez, esta alianza, sostiene Huidobro, no estimula el desarrollo industrial y, en cambio, favorece a la banca y al capital extranjero que explota las riquezas nacionales. El parlamentarismo no posee representación ciudadana ni controla los malos manejos, y el poder judicial no se ejerce en forma ecuánime. El gran problema, según Huidobro, es que no hay nación porque se ha extraviado el "alma", de modo que es necesario, al

${ }^{4}$ Emar en las Notas de Arte de La Nación en junio de 1925, señala que había "llegado el momento de hablar en Chile de Huidobro en Chile". Notas de Arte. Juan Emar en La Nación (1923-1927). Estudio y Recopilación P Lizama Santiago: Dibam-Ril Editores, 2003:171.

${ }^{5}$ Juan Florit afirma que a comienzos de 1925 los miembros de la revista visitaron a Huidobro, quien recién había regresado de París: "Le visitamos en su casa de la calle San Ignacio 56. Nos festejó con los vinos de su viña, autografiándonos sus novedosos libros. Su conversación era cordialísima, con palabras siempre creadoras". Juan Florit. Caudillo de los veleros. Vida. Poesía. Prosa. Introducción, recopilación, bibliografía y notas Andrés Florit. Santiago de Chile: Cuarto Propio, 2006: 25. 
igual que en la poesía, crear "un mundo nuevo" que rompa con la lógica habitual y dé origen a un "hecho nuevo". Hay que trabajar por la "regeneración de la Patria" y por ello, el poeta creacionista se impone como deber "despertar" y "hacer nacer" a una juventud libre y comprometida, por lo que funda Acción, periódico libre, y más tarde dirige La Reforma.

El homenaje es al intelectual que articula la vanguardia artística con la vanguardia política. Así como en el arte, Huidobro manifiesta en 1924 que "nuestra divisa de guerra fue un grito contra la anécdota y la descripción” (Emar 120), así también en la política, señala en 1925 que "nuestro grito de guerra ha sido ... contra la "vieja politiquería"” (Huidobro 138). Él, al regresar a Chile en 1925, despliega con amplitud sus dos grandes anhelos, "crear un poema" y "crear un país", porque existe un campo cultural capaz de recibirlos y apropiarlos 6 . El tributo es entonces al viajero vanguardista, a una presencia extraterritorial que con su literatura y su actividad políticocultural otorga a la revista un núcleo estético-ideológico que la legitima: el discurso y la experiencia de lo nuevo. En definitiva, Ariel reconoce al artista que colabora con eficacia en la instalación y validez de la posición de vanguardia en Chile.

El homenaje, por último, evidencia una aspiración. Huidobro viajó a París, vivió en una metrópoli compleja, abierta, móvil, con un campo cultural autónomo, donde existían "libertades excepcionales de expresión". Como muchos artistas que fueron a la capital francesa, su estadía significó vivir la modernidad, distanciarse de su cultura de origen, gestar vínculos con creadores de diversos países y establecer relaciones nuevas con otras lenguas. Tomando prestadas palabras de Raymond Williams, Huidobro atravesó "la severa prueba de la metrópoli", experimentó un "proceso intenso y visual y lingüísticamente emocionante por derecho propio, del cual surgieron notables formas" y regresó a Chile en 1925, convertido en un actor de la vanguardia (67). Los integrantes de Ariel, en cambio, no han salido del país y viven en una sociedad tradicional, cerrada, estática, en un campo literario que posee solo grados de autonomía y en el cual surgen grupos contestatarios interesados por las propuestas de la modernidad. Los jóvenes de Ariel se inician en la literatura y comienzan a tejer vínculos significativos en Chile y Latinoamérica, de modo que el tributo a Huidobro es a la futura colocación a la que aspiran los encargados de la revista. En síntesis, el homenaje es a la trayectoria de un escritor "faro".

Además de difundir a los referentes del arte nuevo como Huidobro, había que promover a los artistas recién llegados al campo cultural y dar a conocer la poesía de "los temperamentos libres de Chile" e Hispanoamérica. Los textos aparecidos en Ariel conforman una muestra muy interesante, que deja traslucir una etapa de transición en la literatura chilena e hispanoamericana, pues en ella coexisten múltiples proyectos creativos, sensibilidades con marcadas diferencias y variados grados de entendimiento de las tendencias del arte nuevo.

${ }^{6}$ Ver el texto de Gonzalo Aguilar "El cuerpo y su sombra. Los viajeros culturales en la década del veinte", Punto de vista 59 dic. 1997: 30-34. 


\section{IMITAR Y APROPIAR}

La poesía ligada a una concepción romántica que expresa los dolores del yo, las tristezas del desencuentro amoroso y la lejanía de los amantes, escenario en el que la mujer es motivo de desencanto o esperanza de salvación, la encontramos en "Actitud del abandonado" de Fenelón Arce, "Cazador invisible" de Gerardo Seguel, "Cinco" de Manuel Eduardo Hübner, "Muñeca" y "Hombre del Sur" de Gerardo Moraga Bustamante. En estos textos, la mujer es entendida dentro de los roles que le ha asignado el sistema patriarcal, los cuales están ligados al consuelo y al refugio, a la iluminación y la compañía: ella es mediadora para la plenitud del hombre o es figura inasible que se busca y se evoca. Los poemas son anecdóticos y descriptivos, los escritores utilizan un lenguaje convencional y priorizan la función expresiva, de modo que la novedad de algunas imágenes, las desviaciones en el plano semántico y el uso de mayúsculas, sangrías mayores y versos escalonados, es solo formal y surge ajena, superpuesta y en desarmonía con el fondo de lo comunicado.

Las inquietudes del yo, pero trabajadas desde una postura diferente, se encuentran en la poeta María Rosa González. Ella en "Brea”, busca liberarse del imaginario femenino tradicional y postula vivir de otra manera. Desea abandonar una vida apacible -"la vida me tiene como un árbol seco/ Estoy enferma de sentirme sana"- refundarse, experimentar nuevas sensaciones y habitar zonas de realidad negadas a la mujer -"Yo quiero saberme mujer en las selvas". González se desprende de la textualidad poética convencional, encuentra palabras nuevas, desarticula estrofas, usa sangrías mayores y un decir sugerente que asume riesgos. La experiencia emocional se nos presenta más distanciada y novedosa porque la poeta la despoja de las convenciones retóricas, evita la familiaridad comunicativa y la convierte en una poesía concentrada hecha de contrastes y tensiones.

El imaginario de la modernidad, las marcas textuales vinculadas a la propuesta de Marinetti, el vuelo entendido como dominio, nos instalan de lleno en la poesía de Juan Marín. El título, Klaxon, el cosmopolitismo del lenguaje -overall, avanti, morire, klaxon-las onomatopeyas que constituyen el estribillo-Kkkuáaá, Kkkuááá, Kkkuóóónla metonimia -“pies yanquilándicos"- el reiterado léxico de la máquina y su velocidad -ruedas y volante, palancas y embragues-dan cuenta de la fascinación del poeta chileno por la tendencia futurista que propone cantar los descubrimientos científicos y las invenciones de la tecnología, crear formas poéticas propias de la época emergente, capturar el dinamismo universal y plasmarlo como sensación dinámica.

"Klaxon" se puede leer como una cita en verso del Primer Manifiesto Futurista. Los jóvenes, los automóviles y su velocidad, el rechazo del mundo antiguo -mitología, ideal místico, sabiduría- la embriaguez y la locura que conducen a lo desconocido, la convicción de estar "de pie en la cima del mundo", la posibilidad de fundar una realidad nueva y lanzar "el reto a las estrellas", son elementos que el poeta chileno recoge y reacentúa. A la vez, se puede leer como una superación e inversión del mito de Ícaro, porque la pareja humana logra ir más allá de sus propios límites, trasciende su propia naturaleza, se acerca al sol, pero no muere, no cae. El espacio también cambia, es un campo de fuerzas muy distinto a la superficie más o menos estable de las 
antiguas cosmologías y filosofías; el tiempo del torbellino, por último, rompe los ritmos cósmicos de las viejas civilizaciones ${ }^{7}$.

La expansión del espacio y la conquista del aire, antiguo sueño del hombre, significan "el fin de la dependencia terrestre y del reinado oceánico" (Giucci 112). El vuelo de Marín implica así el fin de la tradición del impulso ascendente que representan Ícaro en la mitología griega, más tarde Dante en los poetas del dolce stil novo y San Juan de la Cruz entre los poetas místicos; fin del viaje ascendente de los románticos como Novalis y del descendente de Baudelaire; en la tradición chilena, fin de los intentos de Alsino y Altazor. El viaje en Marín aparece como una superación del imaginario vinculado al vuelo dentro de estas tradiciones, para transformarse en uno moderno, exterior, de conquista y dominio: hay ascenso, pero no hay caída ${ }^{8}$.

Las creencias en "Klaxon" son modernas. El movimiento deja atrás a la quietud; la ciencia y la tecnología, a la naturaleza y a la cultura; Estados Unidos, al mundo grecolatino. El poder del hombre, la confianza en el maquinismo y su capacidad de transformación, las posibilidades de construir(se) ofrecidas por la razón, configuran un ethos cultural moderno, de autonomía y dominación del hombre mediante la técnica de base científica que niega la otredad. Moderno también es el cambio en el modo de percepción sensorial en el arte. De la lentitud pasamos al torbellino; de la contemplación de la pintura y literatura del pasado al dinamismo del cine y con esta nueva percepción, parafraseando a Benjamin, el poema es un viaje de aventuras emprendido entre los dispersos escombros de la civilización antigua.

La paradoja es que estas convicciones no logran fabricar un poema con una estética moderna. La agitación y el vértigo, Marín no los plasma con procedimientos nuevos, no los expresa visualmente en el poema, y más bien indican una lectura que es muy tributaria y dependiente del texto ajeno. Marín escribe a la manera de los futuristas y de esta forma ocurre lo señalado por Huidobro: "Si canto al avión con la estética de Víctor Hugo, seré tan viejo como él”.

La recepción activa que significa transformar la palabra ajena, introducir un material propio y así dar origen a la variación, se encuentra en los textos de Juan Florit. Él agrega otra faceta a la muestra poética, porque, en particular su poema "Viaje", revela un trabajo poético atrayente que modifica nuestra percepción, posee coherencia en el uso de los procedimientos creacionistas y propone una original dislocación de la palabra futurista. El hablante realiza su vuelo en "mi aeroplano de recuerdos", cambio

${ }^{7}$ Ver Octavio Paz. El arco y la lira. México: F.C.E, 1981.

${ }^{8}$ La Barca de Los Diez que abandona el mar y alcanza el espacio en el relato de Pedro Prado, se asemeja en este sentido al auto de Marín que abandona la tierra y asciende al espacio, pero el viaje del navío no es moderno ni futurista, porque más que de dominio y conquista, es de búsqueda y trascendencia. Aunque se deshacen los límites del tiempo y el espacio, no existe voluntad de romper con el orden de la creación. Ver Los Diez Santiago: Universitaria, 1915. 
radical que aleja a Florit del tratamiento futurista de la máquina, y el trayecto ocurre en el momento que precede a la salida del sol, en el umbral que separa la noche del día. Ambas estrategias le permiten al poeta desarrollar un viaje donde la peripecia exterior del aeroplano por el espacio es solo una máscara, porque el vuelo remite a un viaje interior, donde el protagonista no es la máquina y su velocidad, sino el sujeto y su memoria. El "aeroplano [es] de recuerdos", la exploración es a la intimidad del yo, se sitúa en el ámbito amoroso y en la experiencia de ambigüedad y fugacidad que este posee, por tanto, el poema se ubica en las antípodas de las propuestas de Marinetti y Marín.

Las imágenes de Florit se plasman en versos que tienen reminiscencias huidobrianas, pues se ubican en distintas posiciones, en estrofas de variada extensión y configuran una espacialidad al servicio de revelar, también con el código visual, lo dicho con el lingüístico. La marca creacionista también se aprecia en los versos siguientes:

El viento apaga las estrellas atrasadas

\section{Miraban}

El vestido que se puso la mañana

La personificación y en especial la impertinencia predicativa, la espacialidad que destaca la vacilación de sonido y sentido, los desplazamientos y giros que provocan cortes sintácticos y ambigüedades semánticas que se resuelven en relación con otros signos, evidencia otra forma de apropiar el proyecto creacionista.

La mirada más crítica acerca de la modernidad, el desamparo del hombre y la crisis de fundamentos lo encontramos en Ángel Cruchaga. En "La soledad del hombre último", él presiente el fin de la civilización, imagina las problemáticas antropológicas, metafísicas y literarias que plantea el derrumbe final y trata de responder al enigma que cruza el poema: qué le ocurrirá al último hombre cuando quede "solo bajo los cielos" y advenga el fin de los tiempos. El hablante se interna en territorio inexplorado y con lenguaje visionario, tono profético e imágenes apocalípticas, traza el paisaje de muerte que se presentará cuando "hayan muerto las ciudades y los pueblos".

La ruina del universo introduce una interrogante antropológica, pues en ese escenario futuro, el hombre, testigo de la caída, pierde sus atributos más significativos, sus relaciones con la naturaleza, con los demás y consigo mismo, y lleva una existencia desolada, pues condenado a vivir entre cenizas, a sobrevivir con la memoria de la plenitud humana, se transforma en un cuerpo donde solo crece la desgracia. El que tenía amplio poder y dominio sobre la tierra, será "dueño de las islas que lloran"; el que amaba, caminará "llagado de fragancias / de las mujeres... que se han muerto"; el que fue feliz, llevará en sus "ojos todas las agonías": la criatura divina será una "quemadura inextinta de Dios en la tierra". El despojo y el deterioro conducen a una nueva metamorfosis que deja al hombre petrificado -"hombre de piedra", "muro que mira"- y luego vitrificado -"sutil espejo negro", involución que en definitiva culmina con un sujeto postrado, convertido en conciencia expuesta y saturada que contempla su derruida morada. 
El desplome de la modernidad y la pérdida del ser constituyen una condición límite, el hombre deviene en "canción detenida en su curso", en "recodo en la llaga del tiempo", y surge la interrogante metafísica, porque no se advierten señales que indiquen cambios en su estado. El derrumbe no origina un cielo nuevo, este "será un vitral trizado y pudriéndose", no trae la vida sino el señorío de la muerte, no hay revelación de Dios ni signos de su reino. El desamparo y la desesperanza son manifiestos, pues el lugar de Dios es el sitio de su ausencia, el lugar donde resplandece la plenitud del vacío.

La única duda que a su vez cierra el poema, es saber qué le sucederá al hombre al momento de la caída del cielo, último amparo que al desfondarse, indicará la muerte de todo fundamento metafísico capaz de otorgar sentido a la existencia humana. Surge la interrogante literaria: “¿qué huracán de sonidos se entrará por tus venas / cuando como un avión en llamas se caiga el cielo?” El testigo que sobrevive, ¿podrá contemplar y representar la caída del mundo suprasensible o esta será inenarrable?; ¿tendrá aliento y palabras para verbalizar el colapso de la modernidad -“avión en llamas"- y su fundamento metafísico?, ¿encontrará un lenguaje para testimoniar, decir algo o todo será solo un ruido destemplado que antecede al silencio final?

Las problemáticas que vislumbra Cruchaga se radicalizan y establecen una red intertextual con los planteos huidobrianos. Ecuatorial (1918) ofrece la visión de un mundo que se desploma, un hablante que, al igual que en Cruchaga, es el "último sobreviviente del planeta viejo" (Hahn 33), y la agonía del cristianismo con un Dios que abandona la tierra ${ }^{9}$.

Altazor (1931) lleva al límite la representación del fin de los tiempos, porque la crisis del fundamento metafísico y la ruina del cristianismo se hacen evidentes. El Creador no tiene nombre, pues es un "simple hueco en el vacío"; su obra, aunque remite al génesis bíblico, se degrada porque este acto fundacional se encuentra subvertido y el poema anuncia la muerte de Cristo. La desaparición de Dios y del mundo sobrenatural significan que el Creador ha perdido su fuerza constructiva y que el hombre ha perdido su centro, no tiene a qué aferrarse y vive dislocado, en continua metamorfosis: lo único que posee es la memoria del ritmo primero de la creación. Asimismo, la crisis y la ruina implican la subversión de todos los valores y Altazor, a la vez que siente el alivio de la liberación, experimenta la angustia de la soledad, el deseo de absoluto y la búsqueda de eternidad. La poesía surge como respuesta a estos anhelos y se convierte en un nuevo "sagrado".

${ }^{9}$ El testimonio de Larrea es muy interesante, porque recuerda el impacto que le produjo la obra de Huidobro en 1919. Cansinos-Asséns le pregunta a Larrea qué libro le recuerda Ecuatorial y este de inmediato le señala el Apocalipsis, porque "se proyecta a una situación escatológica con todas sus catástrofes, Alfa y Omega, para terminar anunciando el fin del universo". "Vicente Huidobro en vanguardia". Vicente Huidobro y la vanguardia. Revista Iberoamericana 106-107 (ene.-jun. 1979): 213-73. 
Temblor de cielo (1931) no está ajeno a la interrogante metafísica ni a la visión apocalíptica, pues el hombre es concebido como un "náufrago infinito", un ser para la muerte en un mundo donde el cielo se triza y la fe ha desaparecido. El hablante se encuentra sentado "detrás de las rejas del horizonte", ya no espera la revelación divina ni la llegada del reino, sino que coloca su esperanza en la venida del "gran azar" o, al menos, en "la formación de un signo sideral en ese expiatorio más allá"10. La esperanza del sujeto pasa por ser capaz de habituarse a "la nueva luz" y así descifrar, como un vidente, los misteriosos signos del azar, y comunicarlos: "Para esto vivimos... Para esto tenemos voz y para esto tenemos una red en la voz" (De Costa 145). La poesía, una vez más, es la luz en un laberinto sin cristianismo.

Cruchaga afirma que el hombre es "canción detenida / en su curso"; Huidobro, un sujeto nómade abierto a la multiplicidad. La ausencia de Dios, el presentimiento de que el cielo "será un vitral trizado y pudriéndose", son una tragedia para Cruchaga, y de allí la angustia y la voz profética asumida por el hablante, porque advierte una sociedad que se aleja del plan divino y del camino de salvación trazado por Dios. Huidobro, en cambio, radicaliza la crisis, al preguntar: “¿oyes clavar el ataúd del cielo?". Él desaloja a Dios del mundo superior, de modo que "enterrado para siempre", deja un lugar vacío. Si Cruchaga despojaba al hombre de sus atributos, Huidobro le confiere la facultad creadora, otrora rasgo propio del Dios bíblico, para diseñar el cielo en la tierra. En este nuevo mundo, el lugar vacío de Dios es ocupado por la Poesía que se convierte en un nuevo "sagrado", es la nueva palabra, el nuevo evangelio para la humanidad. En carta a Larrea, Huidobro confiesa: "Debemos llenar la vida de poesía, infiltrar la Poesía en todos lados, hacer que el planeta Tierra esté cruzado de Poesía por todas partes" (De Costa 45).

La muestra poética de creadores extranjeros difundida en Ariel, junto a la pluralidad de nuevos temas, presenta semejanzas con los modos de tratar la palabra europea que hemos encontrado en autores chilenos. Además, permite observar la existencia de redes intelectuales bien armadas, y deja entrever las modalidades de cómo aparecen y se reciclan tendencias europeas en el continente.

La transformación de la palabra ajena y la asimilación productiva de distintas tendencias vanguardistas europeas aparece en Ariel con el peruano Julián Petrowick, vinculado desde los inicios al Apra y uno de los fundadores de la sección peruana del partido ${ }^{11}$. Su poema, "Gotas alucinadas", es un conjunto de enunciados breves e

${ }^{10}$ El mundo moderno, señala Paz, ha perdido el sentido y el testimonio más evidente de esta ausencia es el automatismo de la "asociación de ideas, que no está regido por ningún ritmo cósmico o espiritual sino por el azar" (79). El arco y la lira. México: F.C.E, $3^{\mathrm{a}}$ ed., 1981. La otra esperanza es la transformación política, compromiso que se hizo más visible en Huidobro en los años treinta.

${ }^{11}$ Julián Petrowick es el seudónimo de Óscar Bolaño, y "Las gotas alucinadas" forma parte del libro El cinema de Satán. 
ingeniosos que se enmarcan en las greguerías de Ramón Gómez de la Serna, temprano traductor de Marinetti, y autor muy conocido y valorado en el ámbito latinoamericano de la época. Petrowick desarticula convenciones, desplaza al sujeto y arranca los sucesos de su orientación normal en el mundo, de modo que entrega imágenes insólitas llenas de contrastes, que al multiplicar e invertir el sentido, perturban y sorprenden al lector.

Los cambios culturales y el impacto de la tecnología, el hombre que diluye y eterniza los límites de su existencia -"Yo nací un día sin principio y moriré en uno sin fin"- la interrogante por la disociación del yo a través de la pregunta por la sombra o el desenfado para aludir a la mujer, son asuntos bien tratados por Petrowick. Las breves alucinaciones se productivizan con el discurso futurista que sirve para definir dimensiones del sujeto - "los hombres llaman cerebelo al timón del carro de sus cuerpos"- y con el surrealista que permite imaginar realidades insólitas. El cruce y el tramado intertextual de estos discursos, da cuenta de la pronta circulación de las vanguardias y de las múltiples síntesis desarrolladas por los artistas hispanoamericanos.

Las sombras de la ciudad moderna y el radical desacomodo que allí experimenta el hombre, son temas elaborados por Jacobo Fijman, rumano avecindado en Buenos Aires y cercano al grupo martinfierrista. Su poema "Teatro" utiliza el tópico del teatro como ciudad y quien la recorre avanza por "las orillas turbias" de la urbe, trayecto que no es sino una "vasta desolación de idas y venidas" en un escenario que descentra y desnaturaliza al sujeto. Este es un cuerpo enfermo y fragmentado, alienado y solitario, armado de retazos, habitado por el deterioro -"dedos torcidos"- la falta de identidad y autonomía -"juguetes de carne y hueso"- y la alienación -“ojos lamidos por la locura”. La propia ciudad devuelve al sujeto, a través de un verdadero espejo armado con imágenes surrealistas, un ajustado retrato desfigurado de sí mismo y de su condición degradada: "los cristales estúpidos son ojos dilatados / en sarcasmos desconcertantes".

El cuerpo que transita por estas calles no encuentra nunca al otro y deambula por el "teatro gris de la miseria", verso que abre el poema y que se reitera en forma obsesiva a modo de estribillo. La ciudad es una máscara de "alteradas decoraciones", con una trama urbana y con carteles que desorientan y atemorizan; es un espacio donde la vida humana y la creación realizada por el sujeto son un rumor, un lamento fugaz que aparece en el margen y se extravía, "solos de flauta/quejosamente desgranados"; es un laberinto presidido por el silencio y el profundo desarraigo existencial que se torna aún más amenazante con la presencia desconocida e inquietante que domina a la urbe: “Desde adentro quién grita?”

El impulso liberador, de romper los límites y salir del encierro y del silencio atemporal que impone la ciudad se expresa a través del deseo del sujeto de recobrar la unidad que se encuentra disgregada en las numerosas sinécdoques que lo conforman. El hablante anhela habitar otro espacio, abierto, luminoso que le permita hacer un nuevo recorrido, no por las calles oscuras de la miseria, sino por "las calles de la aurora", verdadero estribillo que, correlato del anterior, se transforma en el deseo que cierra el poema.

La poesía chilena e hispanoamericana y la frecuentación reiterada de literatura contemporánea en Ariel queda incompleta si no se complementa con otra tarea imprescindible 
en la fijación de las definiciones del arte: elevar el código de recepción del lector. Este propósito se plasma en textos que ayudan a ampliar el gusto y facilitan un genuino entendimiento y valoración artísticas. Las nuevas voces críticas, una vez más, son los propios artistas de avanzada. Iván Petrov, seudónimo utilizado por Rosamel del Valle, confiesa su dificultad para hacer una exégesis acabada de lo que se entiende por "espíritu nuevo", pero asume que Ariel debe ser una "invitación a percepciones libres", a lecturas distanciadas de preceptos que la limitan. Señala con exactitud que Huidobro y Neruda representan la gestación del arte nuevo, repara en la importancia de los Veinte poemas... y destaca a Ángel Cruchaga, "voz rejuvenecida", pues se aleja del modernismo y se acerca a la vanguardia con sus últimos poemas como "Mi reino" y "La soledad del hombre último". Petrov concluye: él "no está detrás de la hora. Oye las campanas y se va con ellas, atando lo que viene".

\section{PALABRAS FINALES}

Los poetas de Ariel se plegaron al movimiento artístico-cultural emergente en Chile y denunciaron el ordenamiento instalado por la constelación tradicional de elite, colaboraron para renovar y profesionalizar la literatura, construir un orden cultural más abierto que acogiera las tendencias vanguardistas e instalar la posición de la vanguardia en Chile.

La revista, creada por un grupo de artistas que no recibía apoyo institucional de ningún tipo, surge como un espacio significativo para el ingreso de escritores al campo literario y una instancia de difusión y consagración dentro del campo cultural. Ariel da a conocer las corrientes de pensamiento contestatarias, divulga un discurso plural, heterogéneo, y a través de nuevas voces críticas, se suma a la tarea de producir la creencia en el arte nuevo e impugnar el discurso monológico que uniforma el gusto. Su carácter independiente le permite participar y promover el circuito cultural alternativo que existe en Santiago y en provincia, red que representa a nuevos sujetos y logra crecientes grados de autonomía en el campo cultural chileno. Las redes en Ariel no se limitaron al país, sino que se ampliaron a otras naciones, esfuerzo que tuvo múltiples repercusiones y que indica la voluntad de integración y la búsqueda de alianzas para originar transformaciones en Latinoamérica.

Ariel constituye la expresión de nuevos creadores y la circulación de una poética que se enfrenta a las concepciones establecidas. Las obras publicadas en la revista conforman una muestra de la poesía chilena e hispanoamericana a comienzos de los años veinte, la que revela un momento de cambio que se evidencia en la modulación de distintas voces que van desde la sensibilidad romántica hasta la apropiación vanguardista. Si Marín asimila la propuesta futurista y estiliza el conjunto de los procedimientos del discurso ajeno, Florit comprende en forma activa los planteamientos futuristas y creacionistas y los transforma en una poesía con una acentuación peculiar, lo mismo que hace Petrowick con el discurso de Gómez de la Serna y con el surrealismo.

La revista, desde esta perspectiva, contiene diversos fundamentos estéticos e ideológicos. Los poetas jóvenes se han formado en el modernismo, pero se advierte en 
ellos el rumor de la entonación vanguardista, en especial, el aporte del creacionismo y el impacto del futurismo. Los poetas jóvenes son arielistas, pero sienten afinidad con la revolución bolchevique y con la radicalidad del movimiento dadá, y aunque estas adhesiones no se expresan con énfasis ni mayor visibilidad, y su discurso está centrado en los problemas artísticos, ellos no pierden la perspectiva política y participan del debate que ya se advertía entre los artistas e intelectuales respecto al papel del arte y a la tarea del creador en la construcción de una nueva sociedad.

El doble quehacer de Ariel, revolucionar la literatura y transformar las condiciones de la práctica artística, inscribe a la revista en el proyecto más amplio de consolidar condiciones socio-culturales abiertas para incorporar lo nuevo. De esta forma, la revista participa de la dinámica de apropiación cultural de la vanguardia, proceso realizado por los distintos sujetos e instancias del movimiento contestatario, y otorga legitimidad a la vanguardia hispanoamericana.

\section{BIBLIOGRAFÍA}

De Costa, René. Altazor-Temblor de cielo. Madrid: Cátedra, 1983.

Devés, Eduardo. Del Ariel de Rodó a la CEPAL. Buenos Aires: Biblos-Centro de Investigaciones Diego Barros Arana, 2000.

Emar, Jean. Notas de Arte (Jean Emar en La Nación 1923-1927). Estudio y recopilación de Patricio Lizama. Santiago: Dibam/Ril Editores, 2003.

Florit, Andrés (recopilador) Juan Florit. Caudillo de los veleros. Vida. Poesía. Prosa. Introducción, recopilación, bibliografía y notas Andrés Florit. Santiago de Chile: Cuarto Propio, 2006: 25.

Giucci, Guillermo. "Internacionalismo y nacionalismo: el aeroplano". Mester XXXV (2006): 111-127.

Hahn, Óscar. Vicente Huidobro o el atentado celeste. Santiago de Chile: Lom, 1998.

Huidobro, Vicente. Textos inéditos y dispersos. Recopilación, selección e introducción de José de la Fuente. Santiago: Dibam, 1993.

Paz, Octavio. El arco y la lira. México: F.C.E, 1981.

Rodó, José E. Ariel. Selección, prólogo y notas de José Pereira. Buenos Aires: Kapelusz, 1993.

Rodríguez Monegal, Emir. José E. Rodó en el novecientos. Montevideo: Número, 1950.

Williams, Raymond. La politica del modernismo. Buenos Aires: Manantial, 1997.

PALABRAS ClAVE: vanguardia chilena, revista vanguardista, manifiestos, poesía latinoamericana.

KEY WORDS: Chilean Avant-Garde, vanguardist magazine, manifiestos, Latin American poetry. 